\title{
SSR Surveillance Network Optimization With Terrain Masking and Lake Effect Consideration
}

\author{
Jing Guan, \\ Sino-European Institute of Aviation Engineering \\ Civil Aviation University of China \\ Tianjin, China \\ guanjing_cauc@163.com \\ Hantian QI \\ Sino-European Institute of Aviation Engineering \\ Civil Aviation University of China \\ Tianjin, China \\ jhxiaoqi@126.com
}

\begin{abstract}
In this paper, SSR surveillance network covering problem with obstructing affected by surface features and lakes was studied. The purpose is to improve the performance of SSR surveillance network, thus ensure the efficiency and safety management in airspace. The objective is to minimize the number of radar and the decision variable is the site of radar. Firstly, radar network covering problem without obstructing affect is studied. An approximation UFC algorithm was provided. Secondly, covering problem with shelter influence was taken into account. Additional notations were given and SFC algorithm was excuted for this problem. Finally, SSR surveillance network covering problem with obstructing affected by mountains and lakes was studied. We conclude the performance of our algorithm combined with an easy heuristic is stable and can always save one or two radar in the whole system compared to the easy heuristic algorithm.
\end{abstract}

Keywords-SSR Surveillance Network: optimization; coverage problem; approximation algorithm; heuristic

\section{INTRODUCTION}

In recent years, flight number increases every year with rapid development of civil aviation. Safety problems caused by it have become increasingly prominent in the region to ensure no flight collision or tracking target in SSR surveillance system. It makes arrange an effective and stable radar network surveillance system for the whole target area becomes a real problem to be solved.

Since the efficiency of SSR surveillance system depends largely on the role of radar signal distance, many scholars dedicated to the study of signal performance- the distance of signal Role of SSR surveillance system. Omgerg and Norton published literature [1], gave a detailed distance equation of radar signal. D. O. North [2] published the basic theory of signal detection. Later, several Fortran program developed by Blake [3] used to calculate the ground-based radar or free space marine radar distance has been in use for many years. GAO [4] studied how to index a flght by SSR survillance network.

\author{
Hongying $\mathrm{Wu}$ \\ Aviation Automation Institute, Civil Aviation University \\ of China \\ Civil Aviation University of China \\ Tianjin, China \\ hongyingwu@cauc.edu.cn
}

Most study on radar network focus on signal coverage detection of low-level, Such as David K. Barton and J, E. Hanle [5]. Many papers studied location problem, such as [6], while seldom focused on the location of radar. Wang [7] introduced coverage figure effected by terrain Blockage of a given climatic radar network.

Radar network location problem is more like a covering problem but not location problem, which similars to wireless sensor network problems. The wireless sensor is a small device, which can work only with the battery. Many scholars studied scheduling switch of sensor of the network, in order to reduce the consumption of battery, so as to longer the whole use cycle of system, such as Ditian [8]. Zhaozhang [9] provided dynamic programming algorithm in order to monitor some important points along the river. The objective is to mininize energy consumption. Chifu huang [10] and yingshu li [11] studied sensor network $\mathrm{k}$ coverage problems.

Howevere, radar networks and sensor networks are obviously different. Since the radar coverage area is large, a great inflence caused by terrain effect on radar network coverage. The radar is a large equipment, thus construction costs and maintenance costs are near tens of millions yuan. Optimizing radar network will result huge economic benefits. No literature devoted to the study of terrain masking radar network optimization.

In this paper, unsheltered coverage problem, sheltered coverage problem and sheltered coverage problem with lakes influence consideration are studied. We try to minimize the number of radar in SSR surveillance system by location optimization, and thus maximize the performance of radar network. The constraint is the full coverage of the whole area. We assume that effect distance of radar was influenced by terrain masking, and the location of lakes is unsuitable to settle radar in target surveillance area. 


\section{UNSHELTERED FULL COVERAGE MODEL}

In this section, we study full coverage problem to ensure all flights within the region are monitored within the network effective surveillance radar range. When SSR surveillance system works, it emits electromagnetic wave radiation to the azimuth at an elevation angle, which approximates to sphere cone with radar as center. All the aircraft in the sphere cone can be detected by radar. For those flat terrains without tall buildings or mountains block, covering projection of single radar at some height is approximate to one round, then the whole network at some height is intersection of several circular approximately. In order not to leave surveillance blind area in the whole region, various overlap have to be made between different radar coverage regions. Smaller the overlapping area, less the number of radar .

To simplify the problem, we make the following assumptions. The terrain conditions of an area is known. Only one type of radar, and the radar ranges are equal. Radar surveillance elevation are equal, therefore projected radius in one plane are equal. At this point the radar network projector approximate to intersection of rounds with the same radius. Target area is convex polygon.

The problem reduces to coverage problem. The objective is to minimize the number of radar by choosing best location to ensure the whole airspace full coverage. When the number of radar is small, blind area may appear in the entire coverage. When the number of radar increased, the cost of the network increased. Therefore there is a trade-off. Coverage problem is a NP hard problem, there is no polynomial time algorithm, so here we give an approximation algorithm.

\section{A. Unsheltered full coverage algorithms}

Firstly, we note it is easy to arrange radar in the center of square with side length $\sqrt{2}$ for rectangle area. At this time, Number of radar in the target area $S$ is at least $S / 2$.

Algorithm UFC:

Step 1: Establish a cartesian coordinate system with one boundary point as the center. Discrete the target area by a series number of sample points, parallel to the $\mathrm{X}$-axis and $\mathrm{Y}$-axis direction, the step is $\mathrm{h}$.

Step 2: Define a priority of each point, based on the boundary length of sample points it can cover product target area it can cover (area it can cover was calculated by the number of sample points it can cover)

Step 3: Select the highest priority points as the radar site. At the same time the position of the radar coverage area arrange deleted in the total target area.

Step 4: If the target area reduce to tolerance error $e$, end, output the number of radar $n_{1}$. Otherwise, return to step 2.

\section{B. Calculation results}

Matlab was used to program. The rectangle was selected as target area, a vertex was selected as coordinate origin, and the longitudinal direction was selected to parallel to $\mathrm{X}$-axis direction. Radar coverage radius is unit 1 , the target area grid steps $h=0.1$. We admit ending the algorithm under tolerance error $e=0.02$. Different length $a$ and width $b$ of rectangle was selected to test the efficient of the algorithm. Figures 1 is the locations of radar under different length $a=5$ and width $b=4.8$ with the same rectangle area.

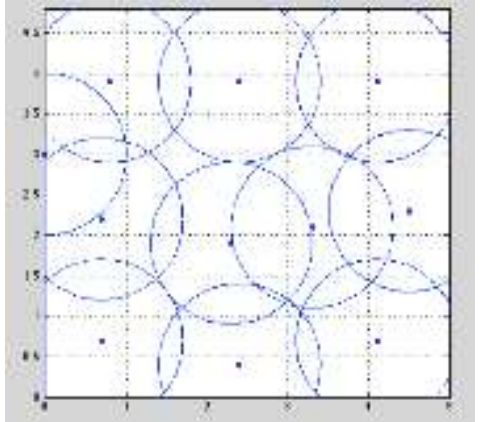

Figure 1. the location of radar for $a=5$ and $b=4.8$

The following table is number of radar under different length $a$ and width $b$ with the same rectangle area.

Table 1: Number of ladar by algorithm UFC

\begin{tabular}{|c|c|c|c|}
\hline $\begin{array}{c}\text { Target area } \\
24\end{array}$ & $\begin{array}{c}\text { Number } \\
\text { of radar }\end{array}$ & $\begin{array}{c}\text { Target area } \\
36\end{array}$ & $\begin{array}{c}\text { Number } \\
\text { of radar }\end{array}$ \\
\hline $\mathrm{a}=6, \mathrm{~b}=4$ & 11 & $\mathrm{a}=9, \mathrm{~b}=4$ & 18 \\
\hline $\mathrm{a}=5, \mathrm{~b}=4.8$ & 12 & $\mathrm{a}=3, \mathrm{~b}=12$ & 17 \\
\hline $\mathrm{a}=3, \mathrm{~b}=8$ & 11 & $\mathrm{a}=6, \mathrm{~b}=6$ & 19 \\
\hline $\mathrm{a}=2, \mathrm{~b}=12$ & 16 & $\mathrm{a}=5, \mathrm{~b}=7.2$ & 20 \\
\hline $\begin{array}{c}\text { Target area } \\
100\end{array}$ & $\begin{array}{c}\text { Number } \\
\text { of radar }\end{array}$ & $\begin{array}{c}\text { Target area } \\
150\end{array}$ & $\begin{array}{c}\text { Number } \\
\text { of radar }\end{array}$ \\
\hline $\mathrm{a}=10, \mathrm{~b}=10$ & 50 & $\mathrm{a}=5, . \mathrm{b}=30$ & 73 \\
\hline $\mathrm{a}=5, \mathrm{~b}=20$ & 48 & $\mathrm{a}=10, \mathrm{~b}=15$ & 79 \\
\hline $\mathrm{a}=4, \mathrm{~b}=25$ & 51 & $\mathrm{a}=20, \mathrm{~b}=7.5$ & 76 \\
\hline $\mathrm{a}=8, \mathrm{~b}=12.5$ & 54 & $\mathrm{a}=25, \mathrm{~b}=6$ & 74 \\
\hline
\end{tabular}

We choose number $\min \left\{\mathrm{n}_{1}, \mathrm{~S} / 2\right\}$ as the final number. Thus we conclude the optimal number we conclude is as following table 2 .

Table 2: Final number of radar network

\begin{tabular}{|c|c|c|c|}
\hline $\begin{array}{c}\text { Target area } \\
24\end{array}$ & $\begin{array}{c}\text { Number } \\
\text { of radar }\end{array}$ & $\begin{array}{c}\text { Target area } \\
36\end{array}$ & $\begin{array}{c}\text { Number } \\
\text { of radar }\end{array}$ \\
\hline $\mathrm{a}=6, \mathrm{~b}=4$ & 11 & $\mathrm{a}=9, . \mathrm{b}=4$ & 18 \\
\hline $\mathrm{a}=5, \mathrm{~b}=4.8$ & 12 & $\mathrm{a}=3, . \mathrm{b}=12$ & 17 \\
\hline $\mathrm{a}=3, \mathrm{~b}=8$ & 11 & $\mathrm{a}=6, \mathrm{~b}=6$ & 18 \\
\hline $\mathrm{a}=2, \mathrm{~b}=12$ & 12 & $\mathrm{a}=5, . \mathrm{b}=7.2$ & 18 \\
\hline $\begin{array}{c}\text { Target area } \\
100\end{array}$ & $\begin{array}{c}\text { Number } \\
\text { of radar }\end{array}$ & $\begin{array}{c}\text { Target area } \\
150\end{array}$ & $\begin{array}{c}\text { Number } \\
\text { of radar }\end{array}$ \\
\hline $\mathrm{a}=10, \mathrm{~b}=10$ & 50 & $\mathrm{a}=5, \mathrm{~b}=30$ & 73 \\
\hline $\mathrm{a}=5, \mathrm{~b}=20$ & 48 & $\mathrm{a}=10, \mathrm{~b}=15$ & 75 \\
\hline $\mathrm{a}=4, \mathrm{~b}=25$ & 50 & $\mathrm{a}=20, \mathrm{~b}=7.5$ & 75 \\
\hline $\mathrm{a}=8, \mathrm{~b}=12.5$ & 50 & $\mathrm{a}=25, \mathrm{~b}=6$ & 74 \\
\hline
\end{tabular}

\section{Conclusion}

We conclude the algorithm is stable. The number did not change too much with $\mathrm{a}$ and $\mathrm{b}$ changing for given target area. About half conditions, the number calculated by algorithm UFC but not S/2 worked, which can save one or two radar for given sample.

\section{SHELTERED FULL COVERAGE MODEL}

If tall mountains or tall buildings exist in some direction, and the height radar-ray emission in this direction is less than the height of the terrain, electromagnetic wave no longer extends far in the 
direction. Radar blind spots appear behind the obstacles. Aircraft in blind spot can not be scanned by the radar. Because of the complex shape of mountains, effective coverage area of radar showed irregular polygon. The effective coverage area varies far away from circular when terrain is complex. SSR surveillance system coverage area can be simply considered as intersection of irregular graphics, thus increasing the difficulty of optimization.

Traditional radar blind calculation process is performed by calculating all shielding planes between each node and radar, getting the maximum security clearance height, and then set it as the blind gap height of the node. Obviously, a large amount of calculation was needed.

In this section we made additional assumptions. Linear function relation between peak point and any point in the mountains was simplified by considering the shape of mountain as cone. Furthermore, definition such as multiplicity, weighted area, corrected distance, and unscan point are introduced to design an easy algorithm.

\section{A. Definiation of multiplicity, weighted area, correction distance and unmeasured point}

Multiplicity. Based on the previous problems, we take hight factors into consideration. Considering the surface area of mountain is larger than planform area, we suppose there exis many layers in this area. Thus the notion of multiplicity about target area are defined as the real surface area divide planform area. For those region exist high multiplicity area, radar radiation 'consumpted' specially in those high multiplicity area, thus unable to form regular circle in the whole region. In the discretization, multiplicity of area is converted into a multiplicity of point, The multiplicity was taken in accout when calculating priority.

Weighted area. weighted area $=$ overlooking area $\times$ multiplicity.

Corrected distance. Corrected distance $=$ height difference +horizontal distance.

Unscan point. Three conditions should be satisfied as following:

(1) The point is within radar range without shelter;

(2) The existence of higher multiplicity point between radar and current point;

(3) Two connections within the allowable range.

\section{B. Sheltered full coverage algorithms}

If there exists just one mountain in the target area, we can arrange radar in the center of square with side length $\sqrt{2}$ for rectangle area, and then settle another radar in the peak of mountain if necessary. At this time, Number of radar in the target area $S$ is at least $S / 2$ or $S / 2+1$.

Algorithm SFC:

Step 1: Establish a cartesian coordinate system with one boundary point as the center. Discrete the target area by a series number of sample points, parallel to the $\mathrm{X}$-axis and $\mathrm{Y}$-axis direction, the step is $\mathrm{h}$.

Step 2: Determine the multiplicity of sample points within the feasible region.
Step 3: Define a priority of each point, based on the boundary length of target region it can cover product target weighted area it can cover.

Step 4: Select the highest priority points as the radar site. At the same time the position of the radar coverage area arrange deleted in the total target area.

Step 5: If the target area reduce to tolerance error e, end, output the number of radar $n_{1}$. Otherwise, return to step 2 .

\section{Calculation results}

Matlab was used to program. The rectangle was selected as target area, the vertex of rectangle was selected as coordinate origin, and the longitudinal direction was selected to parallel to Y-axis direction. Radar coverage radius is unit 1 , the target area grid steps $h=0.1$. We admit ending the algorithm under calculation error $\mathrm{e}$ $=0.02$. the shape of mountain is cone, the height of mountain is 0.5 and the Bottom radius is 0.5 . In the following figure 2 , rectangle with length $\mathrm{a}=4$ and width $\mathrm{b}$ $=6$ of was selected to show the locations of radar with mountains in target region.

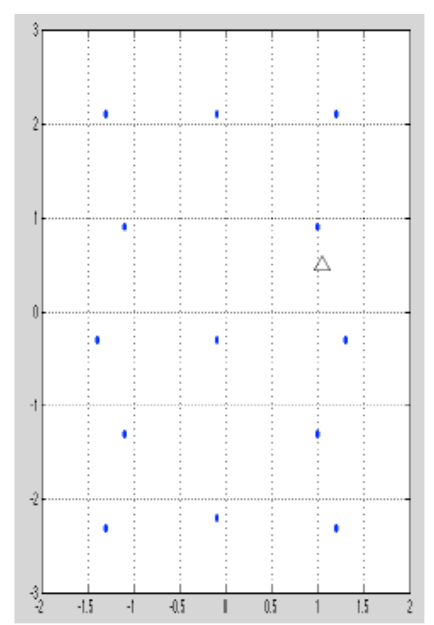

Figure 2. the location of radar for $a=4$ and $b=6$ and the location of mountain is $(3,3.5)$.

The following table is number of radar under different length $a$ and width $b$ with mountain in rectangle area.

Table 3: Number of radar $\mathrm{n}_{1}$ by algorithm SFC

\begin{tabular}{|c|c|c|c|}
\hline $\begin{array}{c}\text { Target area } \\
\mathrm{a}=6, \quad \mathrm{~b}=4\end{array}$ & $\begin{array}{c}\text { Number } \\
\text { of radar }\end{array}$ & $\begin{array}{c}\text { Target area } \\
\mathrm{a}=5, \mathrm{~b}=4.8\end{array}$ & $\begin{array}{c}\text { Number } \\
\text { of radar }\end{array}$ \\
\hline $\begin{array}{c}\text { Mountain } \\
\text { location(4,3) }\end{array}$ & 13 & $\begin{array}{c}\text { Mountain } \\
\text { location(4,3) }\end{array}$ & 11 \\
\hline $\begin{array}{c}\text { Mountain } \\
\text { location(4,0) }\end{array}$ & 15 & $\begin{array}{c}\text { Mountain } \\
\text { location(4,0) }\end{array}$ & 14 \\
\hline $\begin{array}{c}\text { Mountain } \\
\text { location(2,2) }\end{array}$ & 14 & $\begin{array}{c}\text { Mountain } \\
\text { location(2,2) }\end{array}$ & 13 \\
\hline $\begin{array}{c}\text { Mountain } \\
\text { location(1,1) }\end{array}$ & 11 & $\begin{array}{c}\text { Mountain } \\
\text { location(1,1) }\end{array}$ & 13 \\
\hline $\begin{array}{c}\text { Target area } \\
\text { a=3,b=8 }\end{array}$ & Number & $\begin{array}{c}\text { Target area } \\
\text { of } \text { radar } \mathrm{b}=12\end{array}$ & $\begin{array}{c}\text { Number } \\
\text { of radar }\end{array}$ \\
\hline $\begin{array}{c}\text { Mountain } \\
\text { location(1,1) }\end{array}$ & 12 & $\begin{array}{c}\text { Mountain } \\
\text { location( } 1,6)\end{array}$ & 15 \\
\hline $\begin{array}{c}\text { Mountain } \\
\text { location(1,3) }\end{array}$ & $\begin{array}{c}\text { Mountain } \\
\text { location(2,9) }\end{array}$ & 15 \\
\hline $\begin{array}{c}\text { Mountain } \\
\text { location(2,5) }\end{array}$ & 12 & $\begin{array}{c}\text { Mountain } \\
\text { location(2,12) }\end{array}$ & 16 \\
\hline $\begin{array}{c}\text { Mountain } \\
\text { location(3,7) }\end{array}$ & 116 \\
\hline
\end{tabular}


We choose number $\min \left\{\mathrm{n}_{1}, \mathrm{~S} / 2+1\right\}$ as the final number. Thus we conclude the optimal number we conclude is as following table 4 .

Table 4: Final number of radar network

\begin{tabular}{|c|c|c|c|}
\hline $\begin{array}{c}\text { Target area } \\
\mathrm{a}=6, \mathrm{~b}=4\end{array}$ & $\begin{array}{c}\text { Number } \\
\text { of radar }\end{array}$ & $\begin{array}{c}\text { Target area } \\
\mathrm{a}=5, \mathrm{~b}=4.8\end{array}$ & $\begin{array}{c}\text { Number } \\
\text { of radar }\end{array}$ \\
\hline $\begin{array}{c}\text { Mountain } \\
\text { location(4,3) }\end{array}$ & 13 & $\begin{array}{c}\text { Mountain } \\
\text { location(4,3) }\end{array}$ & 11 \\
\hline $\begin{array}{c}\text { Mountain } \\
\text { location(4,0) }\end{array}$ & 13 & $\begin{array}{c}\text { Mountain } \\
\text { location(4,0) }\end{array}$ & 13 \\
\hline $\begin{array}{c}\text { Mountain } \\
\text { location(2,2) }\end{array}$ & 13 & $\begin{array}{c}\text { Mountain } \\
\text { location(2,2) }\end{array}$ & 13 \\
\hline $\begin{array}{c}\text { Mountain } \\
\text { location(1,1) }\end{array}$ & 12 & $\begin{array}{c}\text { Mountain } \\
\text { location(1,1) }\end{array}$ & 13 \\
\hline $\begin{array}{c}\text { Target area } \\
\text { a=3,b=8 }\end{array}$ & $\begin{array}{c}\text { Number } \\
\text { of radar }\end{array}$ & $\begin{array}{c}\text { Target area } \\
\mathrm{a}=2, \mathrm{~b}=12\end{array}$ & $\begin{array}{c}\text { Number } \\
\text { of radar }\end{array}$ \\
\hline $\begin{array}{c}\text { Mountain } \\
\text { location(1,1) }\end{array}$ & 11 & $\begin{array}{c}\text { Mountain } \\
\text { location(1,1) }\end{array}$ & 13 \\
\hline $\begin{array}{c}\text { Mountain } \\
\text { location(1,3) }\end{array}$ & 12 & $\begin{array}{c}\text { Mountain } \\
\text { location( } 1,6)\end{array}$ & 13 \\
\hline $\begin{array}{c}\text { Mountain } \\
\text { location(2,5) }\end{array}$ & 12 & $\begin{array}{c}\text { Mountain } \\
\text { location(2,9) }\end{array}$ & 13 \\
\hline $\begin{array}{c}\text { Mountain } \\
\text { location(3,7) }\end{array}$ & 11 & $\begin{array}{c}\text { Mountain } \\
\text { location(2,12) }\end{array}$ & 13 \\
\hline
\end{tabular}

\section{Conclusion}

We conclude the algorithm is stable. The number did not change too much with $a$ and $b$ changing for given target area. More than half conditions, the number calculated by algorithm UFC but not $\mathrm{S} / 2+1$ worked, which can save 3 radar for given sample at best condition. By algorithm SFC, the location is always not in the peak of mountain. In fact, it will bring less maintenance and Construction cost.

\section{BOTH LAKES AND MOUNTAIN EXISTES MODEL}

Furthermore, the existence of lake additional to mountain sheltered was considered in this section. Those points located in the lake can not be chose as location of radar.

The following figures 3 is locations of radar with lake in target area.

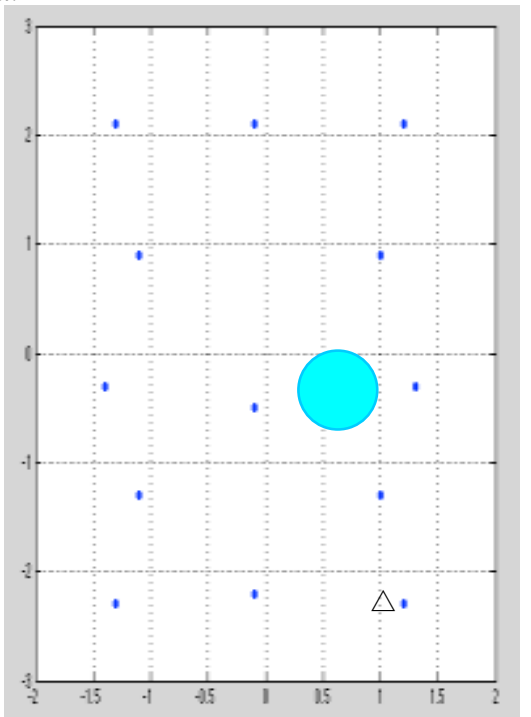

Figure 3. the location of radar for $a=4$ and $b=6$ and the location of mountain is $(3,0.5)$.
The algorithm and data are the same as those in sheltered full coverage model. The shape of mountain is cone, the height of mountain is 0.5 and the Bottom radius is 0.5 . the target region is rectangle with $a=6, b=4$. The shape of lake is round with radiu 0.3 , the center of lake is location in $(x, y)$.

The following table 5 is number of radar under different length $a$ and width $b$ with mountain in rectangle area.

Table 5: Final number of radar network

\begin{tabular}{|c|c|c|c|}
\hline $\begin{array}{c}\text { Mountain } \\
\text { location(1,1) }\end{array}$ & $\begin{array}{c}\text { Number } \\
\text { of radar }\end{array}$ & $\begin{array}{c}\text { Mountain } \\
\text { location(2,2) }\end{array}$ & $\begin{array}{c}\text { Number } \\
\text { of radar }\end{array}$ \\
\hline $\mathrm{x}=3, \mathrm{y}=3$ & 12 & $\mathrm{x}=3, \mathrm{y}=3$ & 14 \\
\hline $\mathrm{x}=4, \mathrm{y}=5$ & 12 & $\mathrm{x}=4, \mathrm{y}=5$ & 14 \\
\hline $\mathrm{x}=6, \mathrm{y}=1$ & 12 & $\mathrm{x}=6, \mathrm{y}=1$ & 14 \\
\hline $\begin{array}{c}\text { Mountain } \\
\text { location(4,0) }\end{array}$ & $\begin{array}{c}\text { Number } \\
\text { of radar }\end{array}$ & $\begin{array}{c}\text { Mountain } \\
\text { location(4,3) }\end{array}$ & $\begin{array}{c}\text { Number } \\
\text { of radar }\end{array}$ \\
\hline $\mathrm{x}=3, \mathrm{y}=3$ & 15 & $\mathrm{x}=3, \mathrm{y}=3$ & 13 \\
\hline $\mathrm{x}=4, \mathrm{y}=5$ & 15 & $\mathrm{x}=4, \mathrm{y}=5$ & 13 \\
\hline $\mathrm{x}=6, \mathrm{y}=1$ & 15 & $\mathrm{x}=6, \mathrm{y}=1$ & 13 \\
\hline
\end{tabular}

We conclude the algorithm is stable. The number did not change too much with $x$ and $y$ changing for given target area. The number changed with mountain location changing.

\section{CONCLUSION}

The infrared detection device, an image sensor and other military facilities are similar to radar network, thus the method can be extended to a variety of military sensor hybrid network problems. Shortage of the paper is neither curvature of the earth nor atmospheric absorption taken into account.

\section{ACKNOWLEDGEMENTS}

This paper is supported by the Fundamental Research F unds for the Center Universities NO. ZXH2012H002, F und for the Doctoral Program of CAUC 08qd02S, Tian jin city application basis and cutting-edge technology $r$ esearch program 13JCYBJC42300.

\section{REFERENCES}

[1] Omberg A C, Norton K A, The maximum range of a radar set, Proc. IRE 35(1947), 4-24.

[2] North D O, An Analysis of the Factors Which Determine Signal/ Noise Discrimination in Pulsed Carrier Systems, Proc. IEEE 51(1963), 1015-1028.

[3] Blake L V. A, FORTRAN Computer Program to Calculate the Range of a Pulse Radar. NRL Report, (1972), 7448.

[4] GAO T, ZHANG X W, Evaluation Index System Research of Secondary Surveillance Radar Location in Air Traffic Control, value engineering, 30(2011), 55-56.

[5] David K Barton , Harold $\mathrm{R}$ Ward. Handbook of Radar Measurement. Washington: ARTECH HOUSE, INC, 1984.

[6] Zhang G Z, SU T S, The Algorithm for Two Location Problems and Some Related Conclusions, journal of national university of defense technology, 12(1990), 1-7.

[7] WANG S D, PEI C, GUO Z M, Evaluations on Chinese Next Generation Radars Coverage and Terrain Blockage Based on SRTM Data, climatic and environmental research, 16(2011), 459468. 
[8] Di Tian, Nicholas D Georganas. A coverage-preserving node scheduling scheme for large wireless sensor networks. WSNA'02, September 28, 2002, Atlanta, Georgia.

[9] Zhao Zhang, Dingzhu Du. Rodar placement along banks of river. J Comb Optim. 2012, 52: 729-741.

[10] Chifu Huang, Yuchee Tseng. The coverage problem in a wireless sensor network. Mobile networks and applications. 2005, 10: 519528.

[11] Yingshu Li, Shan Gao. Designing k-coverage schedules in wireless sensor networks. J Comb Optim. 2008, 15: 127-146. 